\title{
The Pandemic Like No Other
}

\author{
Manoj Kumar Sahu ${ }^{1}$ \\ ${ }^{1}$ Intensive Care for CTVS, All India Institute of Medical Sciences, \\ New Delhi, India
}

J Card Crit Care:2021;5:76-78

The coronavirus 2019 (COVID 19) pandemic has been a worldwide catastrophe. Four centuries after the plague pandemic, this highly contagious RNA virus (SARS-CoV-2) has become a nightmare due to its relentless spread, infecting millions of people worldwide with an unpredictably higher fatality, and the sequelae yet to follow. This viral disease has devastated the world population in many ways. It has affected all stages of life, starting from the rarest vertical infection from mother to newborn to school children to younger working people and the elderly, with or without the co-associations of other diseases, and men as well as women, although with variation in infectivity and fatality, but no one is spared. Most importantly, the medical fraternity bore the brunt because of the sheer profession and its imminent hazard. The year 2020 has become a real suffering for global citizens-rich, poor, ill, healthy, educated, uneducated, the powerless, and the mighty all alike. It has taken everyone by surprise, as if something like this has never happened before.

Novel coronavirus 2019 has been notorious in many waysthere isn't a symptom that is not seen in people infected by this virus and almost all the body organs (the lungs, the heart, the blood vessels, the brain, the gastrointestinal system, and many others) are affected. Characteristically, a highly contagious disease spreads by human to human contact and via droplets/ aerosols, which leaves the community including the health care workers (HCWs) dumbfounded. Although described as less fatal than its predecessors-severe acute respiratory syndrome (SARS) 2003 and middle east respiratory syndrome (MERS) 2012-it defied this proven concept by its unpredictability. Not a single antiviral or any repurposed drug has been very successful in curtailing the progress of the disease once this virus infects a person. This is the cause of fear, anxiety, and distress among common people and doctors alike.

Compared to the 16th century, medical science has advanced leaps and bounds in the 21st century. But SARSCoV-2 has defied all such advances. No specific/targeted treatment could strike the pathogen, only repurposed medicines along with supportive measures have been found to
Address for correspondence Manoj Kumar Sahu, Intensive Care for CTVS, All India Institute of Medical Sciences, Ansari Nagar, New Delhi 110029, India

(e-mail: drmanojsahu@gmail.com).

be effective in the ongoing process of managing all affected people. Although there was success in saving so many lives but no one or more specifically directed agents could prove to be halting the virus. This has been the state of affairs at the end of 8 months of this pandemic, with hit and trial of medicines starting from hydroxychloroquine (HCQ) to remdesivir to dexamethasone to tocilizumab and all others. More than 40,000 publications only on this virus and its spread, contagiousness, and fatality have appeared in almost all medical journals (index and nonindex) within this short span of time. But no amount of study and research has helped in staling the spread of this virus. Here we are.

The world has faced multipronged difficulties. Many countries have faced multiple lockdowns-all business and economic activities have come to a standstill during the lockdown period. Business has taken a new turn in this pandemic-more sanitizers and masks than food supplies/stores were seen and promoted and motor companies have started producing face shields and ventilators. This has been the state of affairs.

The medical fraternity-doctors, nursing staff, technicians, and all levels of HCWs-is working under constant stress and threat to life; sadly enough many of them have lost their lives to this deadly virus. All the medical specialties diverted their resources, logistics, and manpower to cater to this fatal disease; therefore, other patients have been unable to avail direct services from their specialized doctors/hospitals. Yes, the advanced telemedicine facility has been made available to a great extent to help the needy, but is this a perfect way of treating/providing medical care? Can this cover all the needy patients in every corner of the world? Is the teleconnectivity available in every part of the world to cater to and provide services to all? What about people who need surgical treatment for their pathologies? What about those having malignancies, for whom time matters; every single day matters for them, their life days are numbered, and their suffering knows no bounds! What about the end-stage organ failure patients waiting to get organ transplantation? Even if the organ is published online

February 24, 2021
DOI https://doi.org/

$10.1055 / \mathrm{s}-0041-1723860$

ISSN 2457-0206.
(C) 2021. Official Publication of The Simulation Society (TSS), accredited by International Society of Cardiovascular Ultrasound (ISCU).

This is an open access article published by Thieme under the terms of the Creative Commons Attribution-NonDerivative-NonCommercial-License, permitting copying and reproduction so long as the original work is given appropriate credit. Contents may not be used for commercial purposes, or adapted, remixed, transformed or built upon. (https://creativecommons.org/licenses/by-nc-nd/4.0/)

Thieme Medical and Scientific Publishers Pvt. Ltd., A-12, 2nd Floor, Sector 2, Noida-201301 UP, India 
available, is it safe to proceed with the transplantation surgery without extra risk? What about the patients with other diseases and ailments? It is not easy to calculate the burden of untreated people suffering from other illnesses like diabetes, hypertension, arthritis, cancers, obstetric problems, and the surgical disciplines-all were hit hard by this pandemic.

While many other professionals work from home, avoiding contact and spread of COVID 19, the HCWs work directly for the virus-infected patients. They too are stressed by the fear of being infected by this highly contagious and potentially deadly virus, by the fear of infecting their family, and by the constant reminder of their own death. Beside this, the psychological aspects of human mental health have been affected to a great extent by this pandemic. Many people, including the medical fraternity, have been affected by the neuronal disturbances; incidences of new onset of severe depression, including suicide, have been seen to increase in all sections of the community, which is another scary scenario that needs sincere attention.

Now, what about the children and their education-online education system and its quality, validity, effectiveness, and competitiveness? What would happen to more than half of the world's children who do not have the access to the online education facility and its accessories? Should we leave them behind? What about opening schools? What is the safe time? Should parents give consent to send their children to schools? Many such questions and doubts remain. But there is a grim side of this online education system which sadly deprives millions of children in many developing countries who do not have the access to the Internet, electricity, and laptops/ipads/mobiles or even desktops. It is extremely sad but true-the virus has been a partisan of the elite and rich, denigrating the underprivileged further down. This is the real truth-not only education but also nutrition, hygiene, and other basic necessities are unavailable to many underprivileged sections of the society-this is how we travel most gracefully unequally.

The business now-it was a total shutdown/paralysis of all kind of trade and business, leaving aside the essential things like food and milk during the initial stages of full lockdown, but the phenomena is still continuing after 8 months of the pandemic. Many small and medium businesses-one-person businesses to small group entities-were shattered to a large extent. Many families were deprived of their daily meals in developing countries. Many daily-wage workers had to flee to their home states, leaving the workplaces, due to stoppage of work. This scenario happened not only at intracountry/ interstate levels but also at international levels. So many strange things were seen-people travelled long distances, some thousands of kilometers by foot or bicycle; millions of people were evacuated from foreign countries to the home country; and in the process so many lives were lost due to hunger, stress, other medical ailments, and exertion.

Heart-wrenching stories were heard and seen during this pandemic-people moved to their home states and countries as if there is a war. Could it be a probable hidden biowar? Only time will tell! How devastating and ugly the contagiousness and fatality of this tiny microorganism can be-such is the prowess that it created unruly fear and despair among people in such a large scale, so much so that the world medical research community did not have an early answer. The virus is still unstoppable after 8 months of marathon infectivity and killing.

What is happening at the global stage in this pandemic? Almost all the countries, their governments, and people from all sections-students, teachers, trainers, and researcherseveryone has given their $100 \%$ to halt the spread of this novel coronavirus. The governments strategized the phased process of lockdowns, the unlock timings, and so many activities with regulations from time to time, of course with the humanitarian aid and assistance to all sections of people in so many different ways to sustain life amidst this once-in-a-lifetime devastating crisis. Every country is trying to help the other in so many different ways from providing medicines, personal protective equipments (PPEs), viral testing kits, and laboratory facilities to collaborating research to make vaccines for the world. But some odd ones have created a war atmosphere and tried to take advantage of the crisis situation, strengthening the evidence further that it is a man-made crisis created to achieve more world power by fooling others-it might sound very odd but wouldn't seem to be untrue.

Some say there will be a second wave of infection. Some say the second wave is already over. Community spread or no community spread, the numbers don't lie. It is truly relentless. The world eagerly awaits for the vaccine, the so called amrit (the divinely pious potion making humans immortal) obtained from the churning of the sea (quick and vigorous research), as if the vaccine is going to be the bramhastra (the undefeated weapon) to COVID 19. Should we really believe this? Even if it becomes effective, would it be short term or long term? Herd immunity is not seen yet to prevent the re-infection or so-called second wave of infection.

The COVID 19 pandemic has terrified the world and its uniqueness has raised several questions about its origin, mutation ability, contagiousness, mode of spread, fatality, and so forth. The unabated rapid spread of COVID 19 infection has swept over the world, leaving devastation and despair; it has compelled all of us to worry about the future. The uncertainty around transmission, symptoms, testing accuracy and capacity, treatment modalities, and the risk of lasting complications and death, all have caused fear, worry, confusion, and distress. Is this virus a real natural one? Unfortunately, the world medical society has not been able to prove this. It probably won't be able to do so.

The world has probably not seen such an unparalleled contagious disease before. And in this medically advanced 21 st century, the inability to break the journey of this virus proves that there is something above all of us-the power of the almighty (the God), who is probably treating the world for the sins in this kalyug as per Hindu mythology, if it is to be believed. It is He who is doing everything to warn the people to walk on the true path, the dharma, to be liberated from this suffering.

\section{Conflict of Interest}

None declared. 